and $\mathrm{H}_{2}$ combine to form $\mathrm{NH}_{3}$ under the influence of the silent electric discharge, while at the temperature of the spark-discharge $\mathrm{NH}_{3}$ is again split up into $\mathrm{N}_{2}$ and $\mathrm{H}_{2}$. The running down also of $\mathrm{HNO}$, through the whole series of oxides into ammonia in the Grove cell is full of interest from this point of view, and the subject, with its manifold ramifications, is a fascinating theme for a thesis.

Bishop's Stortford, May 30 .

A. IRVING.

\section{An Inverted Slab in a Cromlech.}

rHE remarkable articles on Stonehenge and other monuments by Sir Norman Lockyer have naturally stimulated reflection upon all that concerns megalithic remains, and therefore, perhaps, the following curious circumstances may be of some interest.

At Henblâs, in Anglesey, is a cromlech, or rather, I suppose, a dolmen, of remarkably rude and massive aspect. Two uprights remain, the larger of which is about ${ }_{5} 5$ feet high by 9 feet thick, and both are very rough and irregular in shape. Resting against these, at an angle of about $20^{\circ}$ or rather less from the horizontal, is a thinner stone, about 3 feet thick and some 13 feet square, presumably a top-stone. All are of a hard quartzite, which occurs among the schistose rocks of the district. No good exposure of this is known within a mile or so of the cromlech (a fact which Captain Evans, of Henblâs, informs me was pointed out to him long ago by Sir Andrew Ramsay). But at the base of the uprights are some obscure exposures that appear to me to be in situ, and I. am inclined to think, therefore, that the materials were obtained on the spot.

Now the supposed top-stone is rough, like the uprights, on its upper surface, but its under-side is beautifully and finely ice-worn! It is clear, therefore (for it is certainly not a boulder), that it has been turned upside down.

Further, not only is it ice-worn, but the direction of the ice-movement can be made out, there being distinct lee-sides to its finely striated bosses, and these lee-sides look to N.N.E. But the natural direction of glaciation in the district is to S.S.W. Therefore, the stone has not only been turned upside down, but turned round as well.

If the materials were brought from some distance, these facts are, of course, of less interest. But if, as I think much more probable, they were obtained on the spot, it is clear that they throw a little light upon the proceedings of the builders in their work of lifting these great stones.

Achnashean, near Bangor. Edward Greenty.

\section{The Cleavage of Slates.}

I FIND that I owe Mr. Fisher some apology for a carelessly worded allusion in my notice of Dr. Becker's memoir (p. 2o, May 4). In pointing out that the theory which I criticised had been anticipated by Mr. Fisher, I ought, perhaps, to have mentioned that the latter had somewhat qualified his original hypothesis, though the postscript notifying this qualification was, I believe, only privately printed.

Mr. Fisher's further contribution to the question (pp. 55, 56 , May I8) is of interest. If it be granted that the cleavage of the Westmorland slates coincides with the plane of greatest distortion, it becomes less necessary to urge the case of the colour-spots in the Llanberis slates; but the suggestion that these have been formed subsequently to the cleavage seems to raise some difficulty. I have seen examples in which the ellipsoidal green spots are shifted by small faults, which are quite obsolete planes of weakness. This seems to imply that the faults, and $a$ fortiori the spots, are older than the cleavagestructure.

St. John's College, Cambridge, June 7

\section{The Inheritance of Acquired Characters}

Is the following an instance of such inheritance? Lately I heard a missionary at a May meeting tell of the marvellous facility with which Chinese children memorise whole books of the Bible; the four Gospels, and sometimes the Acts also, being an easy feat for children of ten or twelve years. Having carefully sought information from other authorities, I find these facts confirmed, and that the same applies to Mohammedan children. We are aware that for ages their ancestors have been compelled to memorise long portions of their sacred books, and although occasionally we meet with a child of any nation with a gigantic memory, that differs widely from the case of a people where it has become a general characteristic. June 7 .

W. Woods Sмyтн.

\section{THE UTILITY OF AN ANTHROPOMETRIC SURVEY.}

THE Government which has shown so scientific a spirit as to create a Council of Defence, a constant spirit of intelligence to safeguard the Empire amid the development of armaments of other nations, might surely devote attention to that recommendation which stands first in the report of the interdepartmental committee on physical deterioration :- "With a view to the collection of definite data bearing upon the physical condition of the population, the committee think that a permanent anthropometric survey should be organised as speedily as possible. ..."

What are the results to be expected from such a survey as was sketched out at the Cambridge meeting of the British Association last summer? An improvement in the education of the people will surely follow.

At the time of the Elementary Education Act, 1870 , the re-distribution of the populace, that progressive change by which the increasing majority become citizens and cease to be country folk, was not realised. The increasing demands of intellectual exercises upon the time of the children and loss of domestic education were not foreseen, or their effect in making the requirement most urgent that the physical side of education should be brought under educational authority or otherwise definitely provided for. Hence a generation passes and there is an outcry for physical education. Let us hope a coming generation may not be crying in turn that the moral side of education suffers from want of due attention.

The effect of registration-the national survey of deaths-has been a clear guide and a very great safeguard to the public health. One may quote some of the words of Dr. Farr which are to be found in his first letter to the first annual report:- " Diseases are more easily prevented than cured, and the first step to their prevention is the discovery of their exciting causes"; again, "indirect influence (of these reports) upon practical medicine must have been very great. The constant endeavour after exactness of diagnosis and precision of nomenclatire is itself a wholesome discipline, which reacts inevitably upon treatment." Who at that time could prophesy the value, topographical and historical, we now find in these reports?

The anthropometric survey will have upon the sphere of education an equally large and discriminating, if often indirect, influence; it will react upon medicine as well as upon education; it will detect any deterioration of the young adult that is due to the factory and workshop; it will determine the influence of environment upon physique, and, as $\mathrm{Mr}$. John Gray says, "without an anthropometric survey, we are in this important question of sound national physique 'like a log drifting nowhere'; with a survey, we should be like a ship, steering by chart and compass to its destination."

In the influence of body and mind upon one another, it is to anthropometry we must look for certainty of judgment. Mr. H. G. Beyer pointed out to the 1 Physical Deterioration; being the Report of Papers and Discussions at the Cambridge Meeting of the British Association, rgo4, on the Alleged Survey. (Occasional Papers of the Anthropological Institute, No. 2.)

NO. 1859 , vOL. 727 
American Association for the Advancement of Physical Education how important it was to make a study of "fatigue" in its relation to training and education, to find out the conditions under which our work has its maximum beneficial effect, and the limits to the exercise of our muscles favouring the performance of intellectual work. From data worthy of credence, he was of opinion that brain work influenced favourably bodily development, as well as vice versá.

The basis of these and similar observations requires to be broad, and it was interesting to note at the Cambridge meeting how the want of the proposed survey was evident to nearly every speaker. Prof. Cunningham has pointed out how changed conditions of life are palpably attended by changes of physical standard, but we have no clear knowledge of these changes, the best facts concerning our country being still those collected five-and-twenty years ago by the anthropometric committee of the British Association. The racial substitution of a dark element for a fair in the population of London, noted by Dr. Shrubsall as an outcome of his investigations on hospital inmates and healthy individuals, demands a survey to determine its extent and nature.

In the remarks upon deterioration, made at the Cambridge meeting by the president, Mr. Balfour, this requirement stands out quite plainly again in his expression of opinion that fresh air has so large an influence upon the physique of the race.

That a knowledge of the conditions of respiration in towns is at the present day of eminent importance is also patent to everyone who may read, in a recent report of the Registrar General, that in the urban districts of England the death rate from respiratory system diseases is no less than double that of the rural districts.

Now while much attention has been paid to the air of schools and buildings, we have no knowledge whether the lung movement-the chest expansionof the town dweller is much less than the countryman's, and the answer of a survey to this question is highly desirable. It may be that want of exercise of lung is a deteriorating influence like bad quality of air.

Now that a practical scheme of anthropometry with a responsible recommendation of such a scheme lies before our legislators, concerning a matter absolutely beyond the reach of private effort, surely the nation cannot afford to despise such knowledge, nor is the day past when this country can give a lead in the organisation of information to aid the public health.

Unlike Sweden, Germany, and Italy, we have no conscripts to form a source of similar information. The methods proposed are simple:- height, weight, chest girth; head-length, breadth, and height; breadth of shoulders and hips; vision and degree of pigmentation are to be measured. Economy and efficiency will be observed by the provision of whole time surveyors instructed at a single centre, and 80,000 adults and 800,000 children should be measured annually, re-visiting each district every ten years.

The eugenics of $\mathrm{Mr}$. Galton are not at present practical politics, though, as an analogous subject, it is interesting to note that the stud books of hunters, shires, and hackneys have not only improved the breed, but raised the standard of health and improved the average of health in horses exhibited.

As to expense, the sum required is less than that spent on stud books, and similar to that of the Geological Survey. Provision is made, though not too liberally, for the survey of the land on which we live; surely it is not too much to ask that a scheme for the survey of the people should be established upon a national basis.

$$
\text { NO. I } 859 \text {, vOL. } 72]
$$

\section{PHOTOGRAPHY AND NATURAL HISTORY.}

$D^{R Y}$ plate photography cannot be altogether regarded as an unmixed blessing. The facilities which it affords to the amateur have brought down upon us a veritable avalanche of books on natural history subjects, some of which had better never have been written.

Mr. Snell's unpretentious little volume is, however, not of this number. On the contrary, it is of its kind excellent, and will prove a boon to those who are fond of nature-photography but, by force of circumstances, are unable to afford an expensive camera or to spend time and money in search of subjects far afield.

Commencing with a most useful chapter on the methods to be adopted in photographing living animals, the author, in the following chapters, demonstrates the practicability of the rules he has

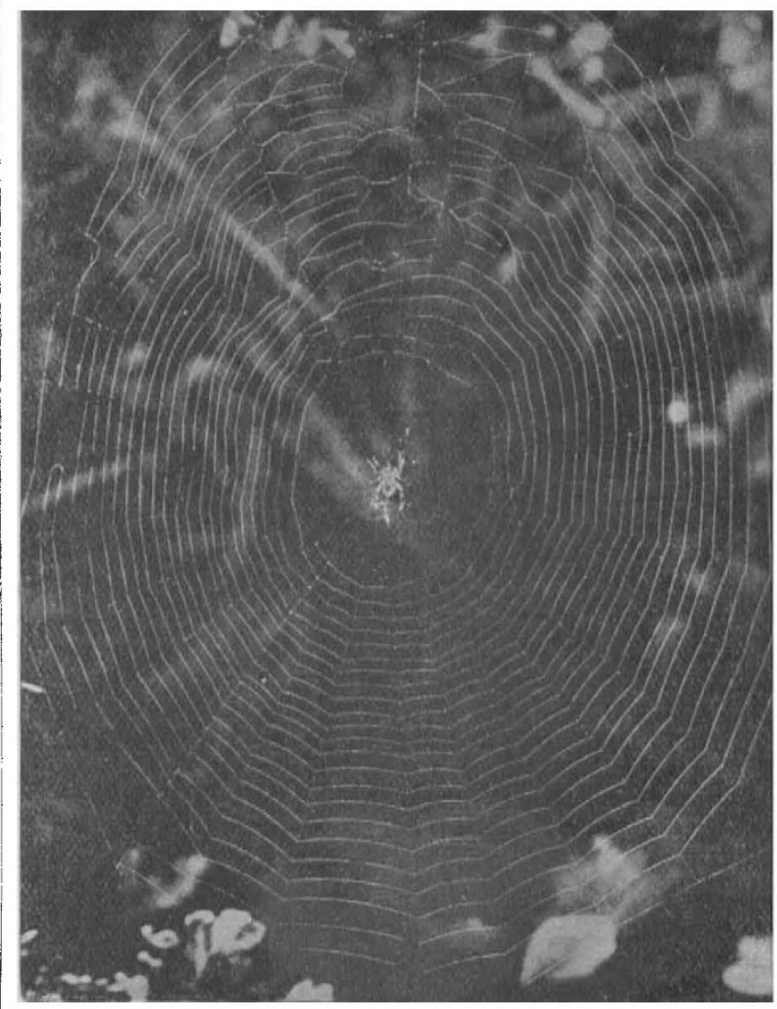

FIG. I. - Spider's Web or Snare. From Snell's "The Ca mera in the Fields.

laid down. Small mammals, birds, reptiles, Amphibia, fishes, and insects are each, in turn, made to furnish illustrations. Finally, some very valuable hints are given on the photography of botanical subjects.

There are tricks, it is said, in every trade! This is notoriously true of photography. Some of the more harmless sort are lucidly described in this volume. The methods, for example, employed in the photography of mice and rats, snakes, and young birds will come as a surprise to many. Many of us, probably, have been amazed at the apparent skill and patience displayed by many "nature-photographers" in securing pictures of field-mice climbing wheat stalks, or rows of nestlings sitting peacefully along a bough. Such pictures, it now appears, may be 1 "The Camera in the Fields." By F. C. Snell. Pp. 256. (London: T. Fisher Unwin, 1905.) Price 5 s. 